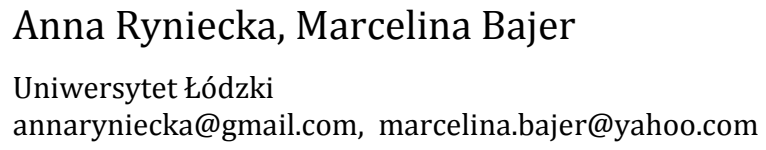

\title{
Różne oblicza Elżbiety II - jaka jest naprawdę?
}

Streszczenie: Królowa Elżbieta II postrzegana jest zazwyczaj jako powściągliwa monarchini Wielkiej Brytanii. Istnieje niewiele osób, które znają jej drugie oblicze - matki, żony, oraz oddanej babci. Niniejszy esej ma na celu ukazanie różnych postaw oraz zachowań brytyjskiej królowej w stosunku do zróżnicowanego kręgu osób. Znajdują się wśród nich rodzina, poddani, a także politycy - zarówno ci brytyjscy, jak i z państw podlegających koronie, czy też najbliżsi sojusznicy. Ponadto esej ten stara się opisać jak wygląda życie królowej Elżbiety za zamkniętymi drzwiami jej pałacu oraz pokazać, że oprócz sprawowania najważniejszej funkcji w państwie, jest ona także zwykłym człowiekiem, który ma takie same potrzeby i problemy jak miliony innych ludzi. Artykuł stara się także podkreślić rolę, którą monarchini odgrywa w swoim państwie, a także uwypukla on kompetencje władczyni Zjednoczonego Królestwa, która sprawuje swoje rządy według znanej zasady - „królowa panuje, a nie rządzi".

Królowa Elżbieta II jest zdecydowanie osobą wyjątkową i godną uwagi. Przedstawia się jako wspaniała monarchini, z oddaniem pełniąca swoją służbę, kochana babcia kilkorga wnucząt i wrażliwa kobieta, kochająca zwierzęta. Królowa zależnie od sytuacji przyjmuje różne twarze. Gdy trzeba, jest konserwatywnym monarchą, bezwzględnie przestrzegającym etykiety, w innych momentach ukazuje oblicze miłej i wyrozumiałej osoby. Nigdy jednak nie daje się ponieść emocjom, zawsze jest zdystansowana i dumna. Przez różne środowiska postrzegana jest w inny sposób. Inaczej odbiera ją rodzina, poddani, czy znane osobistości, które miały z nią styczność. Królowa poznała bowiem w swojej karierze aż 12 premierów Wielkiej Brytanii, a z każdym łączyły ją inne stosunki. Niniejszy artykuł ma za zadanie pokazać różne oblicza królowej brytyjskiej Elżbiety II. 


\section{Zanim Elżbieta II została królową}

Elżbieta II to córka Alberta księcia Yorku, a późniejszego króla Jerzego VI oraz Elżbiety Bowes-Lyon, zwanej później Królową Matką. Urodziła się 21 kwietnia 1926 roku w Londynie, jako wnuczka ówczesnego króla Wielkiej Brytanii - Jerzego V. W 1930 roku narodziła się jej siostra Małgorzata, a jej rodzina mniej więcej do roku 1937 wiodła normalne i spokojne życie, nie myśląc o wykonywaniu królewskich obowiązków. Gdy 20 stycznia 1936r. zmarł król Jerzy V, nikt nie spodziewał się, że jego najstarszy syn Edward VIII - abdykuje niecały rok po objęciu tronu. Jednym z powodów abdykacji była chęć małżeństwa z Amerykanką Wallis Simpson, która była do tej pory już dwukrotną rozwódką. $W$ tamtych czasach było to nie do pomyślenia, nawet wśród dalszych członków rodziny królewskiej, a co dopiero w przypadku świeżo wybranego króla. Edward musiał więc zrezygnować z tronu na rzecz miłości. Drugim powodem abdykacji były pronazistowskie poglądy Edwarda VIII, który uwielbiał Niemców oraz dał się sfotografować w towarzystwie Hitlera. Na tak ekstrawaganckie zachowanie rodzina królewska nie mogła sobie pozwolić. Edward, przez najbliższych zwany Davidem, wyjechał z kraju i zniknął z życia Windsorów, co później odznaczyło się w dużym stopniu na poglądach Elżbiety II. Fakt, że sympatyczny wujek David został zmuszony do opuszczenia rodziny przez jego złe zachowanie sprawił, że królowa w przyszłości bardzo dbała o opinię dworu królewskiego, rodziny oraz o przestrzeganie zasad etykiety. Monarchom nie wypada bowiem angażować się w skandale (Marr, 2012: 52).

Naturalnym następstwem po abdykacji Edwarda VIII była koronacja Jerzego VI - ojca Elżbiety - w maju 1937 roku. Dla jedenastoletniej wtedy Elżbiety oznaczało to ogromne zmiany w życiu, była ona bowiem następna w kolejce do tronu (Rybaczyk, 2012: 4). Już wtedy mała Elżbieta zaczęła przygotowywać się do nowej roli oraz rozpoczęła naukę, między innymi religii, francuskiego, czy jazdy konnej. Podstawowe zajęcia prowadziła z nią guwernantka, natomiast historii uczył jej królewski archiwista. Elżbietę wysłano także do Eton, by przyswajała wiedzę na temat brytyjskiej konstytucji (Marr, 2012: 92). W 1940 roku czternastoletnia Elżbieta wystąpiła na antenie BBC w programie „Children's Hour”, gdzie już wykazywała tendencje zachowania godnego monarchini. Jej majestatyczne przemówienie podczas audycji radiowej miało na celu okazanie wsparcia osobom, które udały się na wojnę oraz ich rodzinom, głównie dzieciom, w których Elżbieta widziała przyszłość dla pokoju (The British Monarchy).

W 1947 roku Elżbieta zaręczyła się, a następnie wzięła ślub ze swoim kuzynem Filipem Mountbattenem. Para poznała się jeszcze w 1939 roku, kiedy to przyszła królowa wraz z rodziną odwiedzała Royal College. Filip zajmował się wtedy oprowadzaniem Elżbiety oraz Małgorzaty, natomiast ta 
pierwsza już od początku zwróciła na niego uwagę. Niestety para została rozdzielona z powodu wojny, Filip służył bowiem w marynarce wojennej (Marr, 2012: 98). Po powrocie z frontu Mountbatten oświadczył się Elżbiecie, która z nieskrywaną radością odpowiedziała „tak”. Po dosyć skromnej ceremonii (Wielka Brytania musiała odbudowywać się po wojnie, dlatego też ślub nie był organizowany $\mathrm{z}$ rozmachem) parze $\mathrm{w}$ końcu udało się połączyć na wieczność. Rok później Elżbiecie i Filipowi urodziło się pierwsze dziecko - drugi za Elżbietą w kolejce do tronu - Karol. Para królewska doczekała się łącznie czwórki dzieci. Dwa lata po Karolu na świat przyszła córka Anna, natomiast kolejna dwójka musiała poczekać aż Elżbieta uporządkuje sprawy związane z odziedziczeniem tronu, i tak w 1960 urodził się Andrzej, natomiast cztery lata później Edward (The British Monarchy).

\section{Królowa Elżbieta II}

Król Jerzy VI, ojciec Elżbiety, był postacią niezwykle ciekawą. Zmagał się z chorobą, która została ukazana w ekranizacji Jak zostać królem. Oprócz tego należy jednak pamiętać, że okres jego panowania nie należał do spokojnych. Król objął tron tuż przed rozpoczęciem II Wojny Światowej i musiał wykazać się ogromną rozwagą oraz dobrym myśleniem strategicznym, aby Wielka Brytania wyszła z tej walki bez szwanku. Stresujący styl życia oraz olbrzymia ilość papierosów, które wypalał, spowodowały u króla chorobę raka płuc (Marr, 2012: 53). Pod koniec panowania Jerzego VI, Elżbieta często wykonywała za ojca jego obowiązki. Tak było również w roku 1952, gdy odbyła z Filipem podróż do Kenii. Wtedy właśnie, 6 lutego, Elżbieta dowiedziała się o śmierci ojca. Do kraju powróciła już jako królowa (Rybarczyk, 2012: 5).

Koronacja królowej odbyła się 2 czerwca 1953 roku. Było to przełomowe wydarzenie $\mathrm{w}$ historii nie tylko brytyjskiej monarchii, ale również telewizji. Po raz pierwszy w historii obywatele mogli uczestniczyć w koronacji, była ona bowiem transmitowana przez stację BBC. Podczas tego wydarzenia tysiące ludzi stało także na ulicach Londynu, aby - mimo padającego deszczu i przenikliwego zimna - choć przez moment zobaczyć królową, jadącą na uroczystość do Westminsteru (Marr, 2012: 152). Od tego czasu królowa Elżbieta II stała się symbolem Wielkiej Brytanii i pozostała tradycyjną oraz konserwatywną monarchinią, mimo rewolucji jaka zaszła w środowisku kulturalnym oraz zmieniających się w błyskawicznym tempie zwyczajów Brytyjczyków. 


\section{Jaka jest królowa na co dzień?}

Jaka jest królowa, przebywając w swoich „komnatach”? Na pewno obowiązkowa. Lubi też mieć wszystko zaplanowane. Każdy dzień zaczyna tak samo, pobudką o 9 rano przez grającego pod jej oknami dudziarza. Podczas śniadania, które jada z Filipem, oboje słuchają radia, siadając następnie do lektury swoich ulubionych gazet. W przypadku Elżbiety, jest to Racing Post - czasopismo o wyścigach konnych. Następnie udaje się do swojego gabinetu, gdzie zajmuje się korespondencją - czyta listy, które jej dostarczono oraz podpisuje różne dokumenty. Zazwyczaj spotyka się również z prywatnym sekretarzem, aby wspólnie podyskutować na temat przyszłych podróży królowej oraz omówić różne, ważne, tajne sprawy. Prawie każdy dzień królowej wygląda pod tym względem tak samo. Monarchini od lat przestrzega harmonogramu, który ułożony jest od samego rana do wieczora (Roche, 2010: 15).

Popołudniami królowa zazwyczaj udaje się na spotkania publiczne, odwiedza różne miejsca takie jak szkoły, szpitale, czy siedziby władz miast/hrabstw, odpowiadając tym samym na zaproszenia tychże instytucji. Każda taka wizyta musi być wcześniej skrupulatnie zaplanowana. Protokół dyplomatyczny stanowi o planowaniu wizyt królowej z dwuletnim wyprzedzeniem. Najważniejsza jest kwestia bezpieczeństwa monarchini. Ta na szczęście podchodzi do zaleceń policji bardzo poważnie (Roche, 2010: 17).

Wieczorami królowa odbywa m.in. raz w tygodniu spotkanie z premierem Wielkiej Brytanii. Ponadto co wieczór dostarczany jest jej raport z obrad parlamentu, który skrupulatnie czyta. Czasami chodzi na premiery filmów, czy różne koncerty i wydarzenia związane z organizacjami charytatywnymi, których jest patronką. Nigdy nie ucieka się do wymówek, że miała ciężki dzień lub że nie ma ochoty, co wynika z obowiązkowości królowej (Roche, 2010: 15).

Elżbieta II, mimo przywiązania do ceremoniału oraz konserwatywnych poglądów, jest niezwykle wrażliwą osobą. Kocha zwierzęta i dba o nie. Często podkreśla, że są one bardziej szczere i przyjazne niż ludzie. Największą sympatią darzy konie, pierwszego zresztą w swojej karierze - kuca szetlandzkiego - dostała jeszcze od swojego dziadka, Jerzego V. Królowa posiada kilkanaście koni, które biorą udział w wyścigach, których monarchini prawie nigdy nie omija. Należą do nich m.in. Royal Ascot, czy Epsom Derby. Oprócz koni, monarchini posiada także psy rasy corgi oraz labradory. Corgi biegają po pałacu i towarzyszą jej w życiu codziennym oraz cieszą się wieloma przywilejami. Królowa jest także jedyną osobą, która może je głaskać, podawać im jedzenie, a także je czesać. Uważa ona również, że jeśli któremuś z psów zdarzy się kogoś ugryźć, jest to na pewno spowodowane niestosownym zachowaniem tej osoby - zwierzęta bowiem nigdy nie są 
winne. Ukazuje to wrażliwość Elżbiety, która na pierwszy rzut oka wygląda na osobę chłodną i zdystansowaną. Gdyby jednak dawała się ona ponieść emocjom, mogłaby nie podołać swojej roli. Królowa bowiem musi być opanowana i myśleć trzeźwo. Ponadto urząd, który sprawuje Elżbieta II wiąże się $\mathrm{w}$ dużej mierze $\mathrm{z}$ samotnością, którą w tym wypadku pomaga jej znieść towarzystwo zwierząt (Roche, 2010: 27).

Elżbieta II mocno trzyma się swoich stalowych zasad. Przestrzeganie protokołu i etykiety jest dla niej najważniejsze, dlatego w kontakcie z nią w grę nie wchodzą żadne poufałości - przytulenie, uścisk dłoni, a już na pewno nie pocałunek. Za takie faux pas potrafi zgromić spojrzeniem. Ponadto królowa nigdy nie mówi „nie”. Jej grzeczna odmowa polega na zadaniu pytania: „Czy uważa pan, że byłoby to właściwe?” (Roche, 2010: 23)

Królowa nie lubi kamer. Stroni od nich jak może, nie udziela wywiadów. Mimo to zawsze prezentuje się wyprostowana i uśmiechnięta, jak przystało na prawdziwego monarchę. Z drugiej strony, lubi zaskakiwać. W 2002 roku zorganizowała bowiem spotkanie dla siedmiuset pięćdziesięciu dziennikarzy, zamieniając z każdym z nich kilka słów i dając się uwiecznić na fotografiach.

Jej Wysokość uwielbia także spędzać czas na wsi. Pozwalają jej na to wakacje, które trwają cztery razy dłużej niż u przeciętnego Brytyjczyka, bo aż 20 tygodni. Wtedy chętnie odrywa się od swoich monarszych obowiązków, zamieniając się na moment w zwykłą kobietę i relaksując się na łonie natury. Ulubioną rezydencją królowej jest Balmoral, zamek w Szkocji, w którym chętnie spędza większość wolnego czasu (polemi.co.uk).

Królowa stara się nie czytać plotek, które o rodzinie królewskiej zamieszczają tabloidy. W swych poglądach jest konserwatywna i może nieco staroświecka, ale pomimo to stara się iść z duchem czasu. Nie stroni od tego co nowe - przekonała na przykład księcia Williama do otworzenia się na prasę, gdyż unikanie reporterów w nie pomaga rodzinie królewskiej w budowaniu pozytywny wizerunku. Jest ona także na bieżąco z nowinkami technologicznymi - swój pierwszy e-mail wysłała w 1976 roku z bazy wojskowej, umie posługiwać się iPodem, a w 2010 roku zwiedziła kanadyjską firmę, produkującą telefony BlackBerry (londynek.net).

\section{Królowa Elżbieta II a rodzina}

Królowa miała zaledwie 27 lat, gdy wstąpiła na tron. Była wtedy młodą mężatką z dwójką dzieci, która musiała wyrzec się swojego życia prywatnego na rzecz monarchii. Obowiązki, oraz sam fakt bycia królową, nie pozwalają jej na prowadzenie normalnego, rodzinnego życia. Nie wolno jej pocieszać w ciężkich chwilach, nie pozwala sobie ona na rozczulanie się nad 
przeciwnościami losu. W stosunku do rodziny jest zdystansowana, a najbliższą jej osobą wydaje się być jej mąż, Filip.

Książę Edynburga wykonuje swoją rolę przy boku królowej niezwykle solidnie, mimo że ciężko mu było się do niej przyzwyczaić. Musiał on bowiem porzucić normalny tryb życia i zacząć ustępować żonie, która w większości spraw ma ostateczne zdanie oraz nie znosi sprzeciwu. Mimo to królowa Elżbieta II zgodziła się, by Filip pozostał głową rodziny i oddała mu czynny udział $w$ wychowaniu ich dzieci. Pokazuje to, że monarchini niezwykle szanuje swojego męża. Świadczyć o tym może także fakt, iż powierzyła mu ona rolę marszałka dworu oraz reformę królewskiej administracji. Filip ma swój wpływ na Elżbietę i to między innymi dzięki niemu królowa tak często spotyka się z poddanymi, mimo że nie lubi nieznajomych ludzi. Ponadto książę Edynburga słynie z niewybrednych żartów, co jednak wprawia królową jedynie w dobry humor i pokazuje, iż ma ona niezwykłe poczucie humoru (Roche, 2010: 64).

Nieco gorsze relacje istnieją między królową a Karolem, u którego Elżbieta nie toleruje wielu cech. Przeszkadza jej jego opozycyjny pogląd na panujący w kraju reżim oraz to, że jest on zwolennikiem Dalajlamy, i że popiera buddyzm oraz islam. Monarchini jest oburzona faktem, że jej syn nie optuje tylko i wyłącznie za tradycyjnym kościołem anglikańskim, jak na prawdziwego brytyjskiego monarchę przystało. Królowa Elżbieta jest bowiem w całości symbolem „brytyjskości”, w przeciwieństwie do swego syna, który opowiada się za wielokulturowością (Roche, 2010: 78). O powściągliwości królowej świadczy natomiast fakt, że gdy dowiedziała się w 1993 roku o romansie Karola z Camillą Bowes-Parker, nie można było się zorientować co czuła. Nie mówiła wiele na ten temat, a jak to ujął jeden z jej przyjaciół, królowa „nawet kiedy mówi o tym co myśli, nigdy nie wiadomo co czuje" (Dempster, Evans, 1993: 7).

Królowa Elżbieta II nigdy nie była wylewna w stosunku do swoich dzieci, życie dworu nie pozwala bowiem na rodzinną tkliwość. Konserwatywność Elżbiety pokazuje tutaj fakt, że - przestrzegając protokołu - dzieci królowej nie mogą przyjść do niej z wizytą bez zapowiedzi. Nie mogą po prostu wejść do gabinetu i powiedzieć „witaj, mamo, co słychać?”. Zawsze muszą bowiem złożyć pisemną prośbę o wizytę. W rodzinie królewskiej miał miejsce szereg kompromitujących wydarzeń - rozwody trójki spośród czworga dzieci królewskiej pary, niefortunne wypowiedzi Karola, czy jego romanse i doniesienia na ich temat, ukazujące się na łamach brytyjskich periodyków w postaci opublikowanych rozmów telefonicznych. Może gdyby Elżbieta poświęcała choć trochę więcej czasu na wychowanie dzieci, dając im prawdziwe, matczyne uczucie zamiast sztywnych zasad etykiety, rodzina nie miałaby tylu problemów? Tego nie wiadomo, choć królowa 
Elżbieta i książę Filip często zadają sobie pytanie, w którym miejscu popełnili błąd w wychowaniu swoich dzieci.

Mimo że królowa nie jest zbyt uczuciową osobą, szczególnie w relacjach z dziećmi, po śmierci Lady Diany bardzo zainteresowała się jej najstarszym synem - Williamem. Książę przejawia cechy podobne do tych, które posiada jego babka - również jest powściągliwy i opanowany, także nie znosi dziennikarzy oraz chętnie spędza czas na świeżym powietrzu. Jej Wysokość stała się dla Williama ewidentnie jedną z najważniejszych osób - książę zazwyczaj słucha jej rad, między innymi to dzięki niej wstąpił do szkoły wojskowej. Elżbieta uważa wnuka za idealny „materiał” na monarchę (Roche, 2010: 85-86).

\section{Królowa a jej poddani}

Obywatele Wielkiej Brytanii już od roku 1953 pokładali w królowej Elżbiecie nadzieje na lepsze jutro. Miała ona dać początek nowej erze i przyczynić się do powojennej odbudowy Zjednoczonego Królestwa oraz do jego rozwoju. By obejrzeć królową, przejeżdżającą ulicami Londynu na uroczystość koronacyjną, ludzie gromadzili się przy barierkach nawet dzień wcześniej, mimo niesprzyjającej pogody - deszczu i zimna (Marr, 2012: 154).

Niestety od 1992 roku monarchia zaczęła przeżywać kryzys - troje z czworga dzieci Elżbiety się rozwiodło, wydano biografię księżnej Diany, w której opisane było, jak bardzo cierpiała ona przez królewską rodzinę, z powodu brak miłości ze strony Karola i nieprzychylności ze strony jego matki. Brytyjczycy natomiast uwielbiali „królową ludzkich serc”, Lady Di i w świetle tych wszystkich skandali, zaczęli coraz gorzej postrzegać monarchię. W tym samym roku królowa zdecydowała się na płacenie podatków, gdyż poddani coraz mniej przychylnie przyglądali się ekscesom członków rodziny królewskiej. Poparcie - nawet dla Elżbiety - spadło, a kulminacja społecznego niezadowolenia nastąpiła w 1997 roku po śmierci Diany. Królowa nie zareagowała wtedy tak, jak poddani by tego oczekiwali zwlekała z powrotem do Londynu ze szkockiej rezydencji oraz nie zgodziła się na opuszczenie do połowy flagi w Pałacu Buckingham. Obecnie zarówno królowa, jak i monarchia ponownie cieszą się ogromnym szacunkiem i uznaniem poddanych.

0 poczuciu humoru i tym, że królowej zależy na swoich poddanych świadczy fakt, że w swoje 80 urodziny w 2006 roku zaprosiła na lunch 100 osób, które urodziły się w tym samym dniu i roku co ona, by móc razem celebrować ten okrągły jubileusz (Banach, 2006). Natomiast w 2012 roku podczas obchodów diamentowego jubileuszu para królewska zaskoczyła 
nowożeńców z Manchesteru, pojawiając się na ich ślubie. John i Frances Canning organizowali wesele w tym samym miejscu, w którym tego samego dnia królowa Elżbieta i jej małżonek spożywali posiłek. Przyszli nowożeńcy dowiedzieli się o tym i wysłali królowej zaproszenie na swoją uroczystość. W odpowiedzi jednak Pałac odmówił im tego zaszczytu. Mimo to w dniu ślubu para królewska zjawiła się na przyjęciu, pozytywnie zaskakując nowożeńców. Królowa wraz z księciem Edynburga przekazała im najlepsze życzenia na nowej drodze życia i udała się na swój posiłek (BBC News).

Można by wymieniać jeszcze krocie przykładów, które pokazują, że królowa jest wyjątkową osobą. Warto wspomnieć jeszcze jednak o sondażach dotyczących Elżbiety II oraz monarchii brytyjskiej. Podczas przygotowań do diamentowego jubileuszu, brytyjska monarchia cieszyła się znowu ogromną popularnością. Ludzie szanują i uwielbiają Elżbietę II, ale nie wiadomo, czy wciąż będą chcieli, aby Zjednoczone Królestwo pozostało monarchią konstytucyjną po jej śmierci. Według ankiety Independent Communications and Marketing, przeprowadzonej w maju 2012 roku, na pytanie czy Wielka Brytania znajdzie się w gorszej sytuacji bez monarchii "tak" odpowiedziało 69 \% respondentów, „nie” - 22\%, natomiast „nie wiem”- 9\% (Clark, 2012). Tymczasem organizacja badawcza Ipsos MORI po badaniu przeprowadzonym 15 czerwca 2012 roku twierdzi, że dziewięćdziesiąt procent obywateli Wielkiej Brytanii jest zadowolonych ze sposobu, w jaki królowa Elżbieta II wykonuje swoje obowiązki. Jest to najwyższy poziom zadowolenia odnotowany od 1992 roku, kiedy pierwszy raz przeprowadzono taką ankietę. Warto dodać, że prawdopodobnie brytyjska monarchia utrzyma się jeszcze przez następne pokolenia, ponieważ z tej samej ankiety wynikało, że książę Karol cieszy się uznaniem wśród 8 na 10 przepytywanych respondentów (Mludzinski, 2012). Ponadto obchodzony w 2012 roku diamentowy jubileusz królowej przebił w liczbie postów wyświetlanych na portalu społecznościowym „Twitter” wydarzenie związane ze ślubem księcia Williama i Kate Middleton (Nelson, 2012).

\section{REIGNS BUT DOES NOT RULE - kompetencje brytyjskiej królowej}

Królowa Elżbieta II jest dziedzicznym władcą Zjednoczonego Królestwa Wielkiej Brytanii i Irlandii Północnej dlatego też formalnie posiada bardzo wiele uprawnień. Pełny tytuł panującej królowej brzmi „Her Majesty Elizabeth the Second, by the Grace of God, of Great Britain, Ireland and the British Dominions beyond the Seas Queen, Defender of The Faith". Tytuł ten wskazuje na ogromny zakres kompetencji państwowych monarchy Wielkiej Brytanii. Zatem Elżbieta II jest zwierzchnikiem sił zbrojnych i ma prawo decydować o zawarciu pokoju bądź wypowiedzeniu wojny, jest głową państwa oraz 
całego Commonwealthu, a od czasów panowania Henryka VIII i uchwalenia w 1534 roku Aktu o Supremacji, angielski władca jest jednocześnie głową Kościoła Anglikańskiego. Także wszyscy członkowie rządu, pracownicy wojskowi i sędziowie składają przysięgę lojalności wobec królowej.

W obecnych czasach najwłaściwsze określenie na uprawnienia monarchy brytyjskiego to: „reigns but does not rule”, czyli królowa panuje, a nie rządzi. Jej kompetencje ograniczają się głównie do funkcji doradczych i reprezentacyjnych. Pomimo prawa do mianowania premiera, czynność ta jest tylko symboliczna, gdyż premierem w Wielkiej Brytanii zostaje zawsze lider partii, która zwyciężyła w wyborach. Gdy żadna z partii nie zdoła uzyskać większości w Izbie Gmin, królowa może zainicjować koalicję. Ostatni raz taka sytuacja wydarzyła się w 1940 roku, gdy król Jerzy VI mianował premierem Winstona Churchilla. Królowa co roku inauguruje posiedzenie parlamentu wygłaszając mowę tronową. Mowa tronowa jest wcześniej przygotowywana przez premiera i rząd, natomiast na oficjalnej inauguracji plany i projekty państwowe odczytywane są przez królową Elżbietę. Kolejnym czysto teoretycznym uprawnieniem monarchini jest prawo sankcji ustaw, prawo łaski i możliwość skorzystania z veta. Ostatni raz prawo veta zostało użyte w 1707 roku przez królową Annę Stuart. Królowa nadaje tytuły szlacheckie, mianuje dostojników Kościoła i nadaje wszelkie ordery i odznaczenia. Oficjalnie monarchini posiada uprawnienia do zawierania i wypowiadania traktatów, jednak te prerogatywy spoczywają na ministrach, którzy w imieniu królowej podejmują decyzje. Faktyczny zakres obowiązków Elżbiety II ukazują trzy prawa: prawo do zachęcania, ostrzegania i rady. Dlatego też w czasie, gdy królowa nie przebywa poza Pałacem Buckingham, tradycją są cotygodniowe spotkania z premierem. Podczas wizyty premiera omawiane są bieżące sprawy państwowe. W Wielkiej Brytanii obowiązują dwie zasady, które tłumaczą ograniczenie kompetencji monarchy jedynie do udzielania rad. Istnieje przekonanie, że król nie ponosi odpowiedzialności, ani politycznej ani konstytucyjnej oraz obowiązuje zasada „król nie może czynić źle” (Balicki, 2003: 50).

\section{Królowa Elżbieta II a premierzy Wielkiej Brytanii}

Królowa Zjednoczonego Królestwa cieszy się niezwykle wielkim szacunkiem najwyższych polityków z każdej strony sceny politycznej, dlatego spotkania i dyskusje monarchini z premierem traktowane są z dużą powagą. Od początku objęcia tronu przez Elżbietę II, w Wielkiej Brytanii funkcję premiera pełniło 12 osób. (Churchill, Eden, Macmillan, Douglas-Home, Wilson, Heath, Callaghan, Thatcher, Major, Blair, Brown, Cameron). Chociaż 
tradycja i etykieta dworska zabrania Elżbiecie II wygłaszania osobistych i stronniczych opinii na tematy polityczne, to jej wieloletnie rządy jako zwierzchniczki Imperium Brytyjskiego sprawiły, że jej głos jest uważnie wysłuchany i respektowany. Elżbieta II znana jest z przestrzegania zasad etykiety, dlatego też trudno jest wskazać, jaki jest jej stosunek do poszczególnych decyzji państwowych. Jej funkcja wymaga od niej ukrywania rzeczywistych opinii o ludziach (Marr, 2012: 38).

Uważa się, że jej ulubionymi premierami byli Winston Churchill, Harold Macmillian i Harold Wilson (sukcesmagazyn.pl). Winstona Churchilla traktowała jak ojca. Opowiadała, że zawsze przychodził do niej w kapeluszu i fraku. Jednakże Elżbieta II nie zawsze słuchała jego rad i wbrew jego opinii, jako pierwszy monarcha Wielkiej Brytanii „wpuściła” media do rodziny królewskiej i uchyliła rąbka tajemnicy z prywatnego życia monarchów. W 1953 roku Elżbieta II zgodziła się na transmitowanie koronacji i umalowała usta na niebiesko, żeby na ekranie telewizora wyglądały jak czerwone. Zapewne nie zdawała sobie wówczas sprawy, że odtąd całe jej życie stanie się własnością publiczną.

Premier Harold Macmillan stwierdził, że królowa kocha swoje obowiązki i bycie królową (number10.gov.uk). Premier wygłosił tę wypowiedź w 1957 roku, jednak pomimo upływu ponad pół wieku nastawienie monarchini do swoich obowiązków się nie zmieniło. Podczas przemówienia do izb parlamentu w pałacu Westminster, Elżbieta II stwierdziła, że pomimo sześćdziesięciu lat spędzonych na tronie nie ma zamiaru abdykować. (sukcesmagazyn.pl). To zdanie szczególnie ucieszyło obywateli Wielkiej Brytanii, ponieważ królowa od wielu lat cieszy się niesłabnącym poparciem swoich poddanych.

Relacje z Edwardem Heathem nie zawsze były najłatwiejsze, głównie ze względu na inne spojrzenie na kwestię integracji europejskiej, którą Heath mocno popierał. Równie napięte były relacje między królową a Margaret Thatcher. Pomimo tego, że obie panie pełniły najwyższe funkcje w państwie zdominowanym przez mężczyzn, to jednak ich charaktery i podejścia do życia różniły się diametralnie. Bojowa Thatcher często nie potrafiła zrozumieć spokoju i niekonfrontacyjnej natury królowej. Pomimo tego, że Elżbieta II nie ujawnia swoich gustów politycznych, wiadome było, że polityka prowadzona przez Thatcher nie była w pełni akceptowana przez monarchinię, a obie panie nie pałały do siebie sympatią. W 1986 roku nastąpił spór o nałożenie sankcji na RPA przez rządy Stanów Zjednoczonych i Wielkiej Brytanii. Thatcher sprzeciwiała się podjęciu decyzji o sankcjach ekonomicznych, jednak królowa wykorzystała swą pozycję i jako głowa Wspólnoty Narodów wywarła wpływ na ostateczne postanowienie i nałożyła sankcje na Republikę Południowej Afryki za politykę apartheidu. Pomimo wielu 
różnic obie panie wyrażały swój podziw wobec siebie. W oficjalnych wypowiedziach Margaret Thatcher często podkreślała doświadczenie i mądrość Jej Królewskiej Mości (wordandfilm.com). W 2005 roku królowa z mężem uczestniczyła w przyjęciu z okazji 80 urodzin byłej pani premier, podczas powitania monarchini Thatcher odniosła się do cotygodniowych spotkań i podkreśliła, że nie są one tylko formalnością i wymianą uprzejmości, lecz rzeczową wymianą poglądów, w których królowa prezentuje doskonałą znajomość bieżących planów i zadań rządu.

Większość z obecnie rządzących polityków w Wielkiej Brytanii nawet jeszcze się nie narodziła, gdy Elżbieta II została królową. John Major, który był premierem w latach 1990-1997 wspominał, że istnieje niewiele osób, które byłyby tak obeznane w temacie problemów współczesnego świata, co królowa. Elżbieta II doświadczyła na własnej skórze przemian zachodzących w XX i XXI wieku. W rozmowie z BBC John Major zaznaczył, że jeśli ktoś nie słucha, co królowa ma do powiedzenia i nie pyta jej o zdanie, traci wyjątkową okazję (natemat.pl).

Relacje z Tonym Blairem na ogół układały się dobrze, zresztą okoliczności przygotowania pogrzebu księżnej Diany pokazane w filmie Królowa w dużej mierze są prawdziwe. W czasie, gdy królowa po informacji o śmierci Diany wyjechała z pałacu Buckingham i nie kontaktowała się z nikim, to właśnie Blair był osobą, która przekonała ją od powrotu i która zorganizowała całą uroczystość. Stosunki premiera z królową nadszarpnęła nieco niedyskretna i „wyzwolona” żona Blaira, Cherie. Często opowiadała w wywiadach o zasadach panujących w towarzystwie królowej, co jest dużym nietaktem. Dzięki wypowiedziom żony Blaira do prasy przedostały się informacje o tym, że królowa nie lubi, gdy osoby w jej towarzystwie zbyt wolno jedzą, wciąż mówią na jeden temat lub spóźniają się.

Przy okazji obchodów diamentowej rocznicy panowania królowej Elżbiety obecny premier Zjednoczonego Królestwa David Cameron, najmłodszy z premierów urzędujących za czasów Elżbiety II, wyraził opinię na temat monarchini podczas wywiadu dla Euronews. Podkreślił podobnie jak jego poprzednicy, że cotygodniowe spotkania z królową nie są tylko narzuconą częścią konstytucyjnych obowiązków, ale ważną i pouczającą rozmową. Zresztą chyba żadna z osób związanych z polityką nie miała tak bliskiego kontaktu z aż dwunastoma premierami Wielkiej Brytanii, co daje możliwość szerszego spojrzenia na sytuację Wielkiej Brytanii i konstruowania wniosków całościowych. David Cameron uważa, że człowiek, który tak wiele zwiedził, poznał właściwie każdą ważną osobistość na świecie może udzielić bardzo dobrych rad, nawet jeśli nie jest specjalistą w danej dziedzinie. Chociaż Elżbiecie II po tak wielu latach panowania nie można tej cechy odmówić. 


\section{Relacje z przedstawicielami Commonwealthu}

Oprócz tytułu Królowej Zjednoczonego Królestwa Wielkiej Brytanii i Irlandii Płn. Elżbieta II jest głową również 15 innych państw należących do Wspólnoty Narodów. Zatem jednym z jej podstawowych królewskich obowiązków jest w reprezentowanie kraju w trakcie podróży zagranicznych oraz wizyty krajach Commonwealthu. Rzeczywiście Elżbieta II spełnia swój obowiązek i przez całe życie bardzo dużo podróżowała. W latach 19531954 odbyła półroczną podróż dookoła świata. Jako pierwszy władca, odwiedziła Australię, Nową Zelandię i Wyspy Fidżi. Często odwiedzała Stany Zjednoczone, Kanadę i Indie.

Jednak to w czasie panowania Elżbiety II nastąpił schyłek Imperium Brytyjskiego. Królowa doskonale zdaje sobie sprawę $\mathrm{z}$ obecnego stanu rzeczy, jednak nie ma żadnego wpływu na zachodzące zmiany. Na terenach brytyjskich terytoriów zamorskich od dłuższego czasu można spotkać się z postulatami o całkowite uniezależnienie się, jednak Elżbieta II cieszy się bardzo dużym poważaniem. Monarchini jest „elementem” spajający system, ponieważ podczas oficjalnych wizyt w krajach Commonwealthu występuje jako głowa poszczególnych państw Commonwealthu. Na co dzień reprezentantem monarchy brytyjskiego w państwach Wspólnoty Narodów jest gubernator generalny, którego mianuje władca Zjednoczonego Królestwa (sukcesmagazyn.pl).

Królowa często pokazuje przywiązanie do Kanady, jednak dwukrotny premier tego państwa Pierre Trudeau nie cieszył się zbytnią sympatią monarchini. Elżbieta II bardzo przestrzega protokółu dyplomatycznego i tego samego wymaga od osób w jej towarzystwie. Lekceważący sposób bycia kanadyjskiego polityka nie przypadł do gustu monarchini, a idealnym przykładem był jego słynny piruet za plecami królowej w 1977 roku. Podczas szczytu państw grupy G7 premier przeszedł obok monarchini i tuż za jej plecami odwrócił się w sposób ostentacyjny, wyszydzając nadmierne przywiązanie Elżbiety II do etykiety. Ten ruch dokładnie zarejestrowały kamery. Problemem okazało się także usuwanie symboli królewskich z budynków na terytorium Kanady, co zmartwiło konserwatywną władczynię (wprost.pl).

Królowa pomimo coraz luźniejszych relacji Wielkiej Brytanii i krajów Wspólnoty Narodów wciąż czuje się za nie odpowiedzialna, a w swoich działaniach jest zdeterminowana. Np. w 1961 podczas podróży do Ghany odmówiła zachowywania dystansu od prezydenta Kwame Nkrumah, mimo że prezydent był celem zamachów. Za idealnego przywódcę Elżbieta II uznaje byłego prezydenta RPA Nelsona Mandelę, z którym utrzymywała serdeczne i nieformalne stosunki. Nelson Mandela mówił o królowej „moja przyjaciółka, Elżbieta" (telegraph.co.uk). 
Przykładem sytuacji , w którym królowa idealnie wywiązała się ze swojej roli doradczej i w pewien sposób arbitrażowej była wzajemna niechęć pomiędzy premierem Wielkiej Brytanii Johnem Majorem a premierem Australii Johnem Hogwardem. Królowa załagodziła nieporozumienia informując Majora, że on podobnie jak premier Australii mają wspólną pasję, krykiet. Major wykorzystał później tę informację w celu nawiązania bardziej przyjaznych i osobistych stosunków z przywódcą australijskim, co zaowocowało lepszą współpracą międzynarodową.

\title{
Elżbieta II a prezydenci USA
}

\author{
„USA i UK to związek serc oparty \\ na wspólnych przekonaniach i ideałach"
} Winston Churchill

Stany Zjednoczone to tradycyjnie najbliższy sojusznik Wielkiej Brytanii, więc nie da się ominąć relacji pomiędzy królową a prezydentami USA. Spotkania pomiędzy najważniejszymi osobistościami w obu państwach są bardzo częste, a stosunki brytyjsko-amerykańskie wykraczają poza współpracę wojskową i dyplomatyczną (london.usembassy.gov).

Za panowania Elżbiety II w USA rządziło 12 prezydentów. Ze wszystkimi, za wyjątkiem Lyndona Johnsona spotkała się osobiście. Harry'ego Trumana poznała zanim objęła tron, natomiast Herberta Hoovera, kiedy ustąpił już ze stanowiska prezydenta Stanów Zjednoczonych. Podobnie jak w przypadku premierów Wielkiej Brytanii, Elżbieta II niektórych prezydentów darzyła szczególną sympatią, a z innymi zachowywała relacje na szczeblu czysto formalnym. Niewątpliwie jednymi z najbliższych królowej prezydentów byli: Ronald Reagan, George H. W. Bush (edition.cnn.com).

George H. W. Bush jest serdecznym przyjacielem królowej, z którym spotyka się również prywatnie. W 1991 roku dzięki zaproszeniu prezydenta Stanów Zjednoczonych Elżbieta II była pierwszym brytyjskim władcą, który uczestniczył w obradach Kongresu. Natomiast syn George’a H. W. Busha, George W. Bush Junior, który również był prezydentem Stanów Zjednoczonych, znany jest $\mathrm{z}$ swoich wielu gaf językowych, co nie mogło umknąć uwadze królowej. Podczas oficjalnego przemówienia prezydent pomylił rok 1976 i stwierdził, że już w 1700 roku monarchini uczestniczyła w obchodach, co można było zinterpretować jako nawiązanie do podeszłego wieku Elżbiety II. Inną sytuacją było zapytanie królowej o to, kto jest uważany za "czarną owcę" w rodzinie Windsorów. Powszechnie wiadome jest, że królowa nie lubi rozmawiać o swoich sprawach prywatnych, a zwłaszcza komentować licznych skandali dotyczących członków rodziny królewskiej (news.bbc.co.uk). 
Wszyscy prezydenci, którzy spotkali się z Elżbietą II wspominali miłą konwersację i wyrażali podziw dla gościnności i sympatii królowej. John Fitzgerald Kennedy w liście z życzeniami urodzinowymi do królowej pisał o bardzo wytwornym i eleganckim przyjęciu jego i jego żony podczas wizyty w Londynie. Podkreślił, że zawsze będzie pamiętał o tym wspaniałym wieczorze i pielęgnował brytyjsko-amerykańską przyjaźń.

Amerykanie znani są ze swojej bezpośredniości jeśli chodzi o kontaktu interpersonalne. Błędu $\mathrm{w}$ zachowaniu etykiety dworskiej nie ustrzegł się także prezydent Jimmy Carter, który podczas wizyty w Pałacu Buckingham podszedł do królowej i zamiast podać rękę pocałował królową. Elżbieta II poczuła się oburzona tym faktem. Do pierwszego spotkania królowej Elżbiety z prezydentem Geraldem Fordem doszło podczas uroczystej kolacji w białym domu, na którą królowa przybyła ze swoim mężem księciem Filipem. Państwo Ford eskortowali parę królewską od samego wejścia. Jednak nie obyło się bez wpadek. Kiedy pary wychodziły z windy, przed nimi ukazał się syn Forda John w samych spodniach od garnituru. Oczywiście od razu przeprosił za niezręczną sytuację, a królowa zachowując dystans, z uśmiechem skomentowała, że nie ma co się przejmować, bo sama jest matką i ma identyczne doświadczenia (Marr, 2012: 326).

Wizyty Ronalda Regana na zamku Windsor nie były czysto formalne. Reganowie byli pierwszą prezydencką parą, która zatrzymała się na zamku Windsor na całą noc. Ronald Reagan podzielał zainteresowania królowej. Dlatego też poza oficjalnymi gestami sympatii fotoreporterzy utrwalili zdjęcia prezydenta i monarchini jeżdżących konno oraz udających się na polowanie. Reagan jest również jednym z trzech amerykańskich prezydentów, którzy otrzymali Order of the Bath, najwyższe odznaczenie, które nadawane jest Amerykanom przez Brytyjczyków (bbcamerica.com).

\section{Protokół dyplomatyczny}

Królowa jest tradycjonalistką w sprawach protokołu dyplomatycznego i ściśle przestrzega wszystkich jego zasad. Co prawda spotkaliśmy się z licznymi wpadkami wielu przywódców tego świata w stosunku do Elżbiety II, ale jak na damę przystało królowa zachowała zimną krew i nigdy oficjalnie nie poprawiła swojego gościa. Jednak omawiając ten temat nie sposób zapomnieć momentu, gdy podczas oficjalnej wizyty George W. Bush Junior pierwszy usiadł za stołem zanim zasiadła królowa. Pierwsza oficjalna wizyta Baracka Obamy w Wielkiej Brytanii także nie obyła się bez wpadek. Michelle Obama objęła królową do zdjęcia, a protokół jasno wskazuje, że poza podaniem ręki na przywitanie, zakazane jest dotykanie królowej. Jako zachowanie nie na miejscu media skomentowały toast Obamy za Elżbietę II. 
W towarzystwie królowej, tylko ona pierwsza może podnieść kieliszek do góry. Do tej zasady nie zastosował się obecny prezydent Stanów Zjednoczonych. Na dodatek wygłaszana przez niego mowa za zdrowie monarchini Zjednoczonego Królestwa była w trakcie, gdy orkiestra królewska zaczęła grać hymn brytyjski (londynek.net).

\section{Bibliografia}

Balicki, Ryszard. Ustroje państw współczesnych. Wrocław: Wydawnictwo Uniwersytetu Wrocławskiego, 2003.

Marr, Andrew. Prawdziwa królowa. Elżbieta II jakiej nie znamy. Tłum. Hanna Pawlikowska-Gannon. Warszawa: Wydawnictwo Marginesy, 2012.

Roche, Marc. Elżbieta II. Ostatnia królowa. Tł. Grzegorz Przewłocki. Warszawa: Wydawnictwo W.A.B, 2010.

Rybarczyk, Marek. „Sześdziesiąt lat panowania królowej Elżbiety II”. Newsweek Historia 2 (2012): 2-33.

Widelski, Robert. „Elżbieta II - Boże chroń królową”. Prestiż (2009): 8-14.

Banach, Anna. Królowa nie całkiem serio. 18.04. 2006. Interia. (http://fakty.interia.pl/newskrolowa-nie-calkiem-serio,nId,809432, dostęp 7.11.2012).

Clark, Tom. "Queen Enjoys Record Support in Guardian/ICM poll". 24.05.2012. The Guardian. (http://www.guardian.co.uk/uk/2012/may/24/queen-diamond-jubilee-record-support, dostęp 5 .11.2012).

Hechinger, Paul. The 'Special Relationship' - A History of Meetings Between British Monarchs and U.S. Presidents. 24.12.2012. BBC America. (http://www.bbcamerica.com/ anglophenia/2012/12/the-special-relationship-a-history-of-meetings-between-britishmonarchs-and-u-s-presidents/11/, dostęp 28 12.2012).

Mludzinski, Tom. Satisfaction with the Queen at Record High. 15.04.2012. Ipsos MORI. (http://www.ipsos-mori.com/researchpublications/researcharchive/2977/Satisfactionwith-the-Queen-at-record-high.aspx, dostęp 17.11.2012).

Nelson, Andrew. Nelson's Column: Queen's Diamond Jubilee Beats Royal Wedding for Tweets. 8.06.2012. Ipsos MORI. (http://www.ipsos-mori.com/newsevents/ca/1094/NelsonsColumn-Queens-Diamond-Jubilee-beats-Royal-Wedding-for-tweets.aspx, dostęp 17.11.2012).

Smith, Sally. The Iron Lady and the Queen: On the Relationship of Thatcher and Elizabeth II. 01.06.2012. (http://www.wordandfilm.com/2012/06/the-iron-lady-and-the-queenon-the-relationship-of-thatcher-and-elizabeth-ii/, dostęp 18.11.2012).

Thorpe, D. R. Queen Elizabeth and Her Twelve Prime Ministers. Number 10. (http://www. number10.gov.uk/history-and-tour/queen-elizabeth-and-her-twelve-prime-ministers/, dostęp 18.10.2012).

Tomiak, Anna M. „Elżbieta II. Od 60 lat samotna na tronie”. 24.04.2012. Sukces Magazyn. (http://www.sukcesmagazyn.pl/artykul/863262.html?p=2, dostęp 14.10.2012).

Turner Graham. "The Real Elizabeth: Part Two". The Telegraph. (http://www.telegraph. co.uk/health/3294556/The-real-Elizabeth-II-part-two.html, dostęp 1810.2012).

Witchell Nicholas. Queen Triumphs amid Bush Gaffes. BBC News. (http://news.bbc.co.uk/ 2/hi/6637549.stm, dostęp: 22 X 2012).

Balmoral Castle - letnia rezydencja królowej i jeden z najpiękniejszych zamków w Europie. 27.05.2011. POLEMI. (http://polemi.co.uk/turystyka-w-szkocji/zamki-i-palace/balmoralcastle-szkocka-twierdza-mapa-dojazd-ceny-bilety-galeria-zdjecia-2788, dostęp 10.11.2012). 
Drugi diamentowy jubileusz. 02.04.2012. (http://www.my21.pl/archiwum/3083-60-lattemu-elbieta-ii-odziedziczya-tron.html, dostęp 20.10.2012).

Marriage and Family. The British Monarchy. (http://www.royal.gov.uk/HMTheQueen/ Marriageandfamily/Marriageandfamily.aspx, dostęp. 20.10.2012).

Queen's Wedding Visit at Manchester Town Hall 'the Best Present'. 24.03.2012. BBC News. (http://www.bbc.co.uk/news/uk-england-manchester-17499716, 05.11.2012).

Techniczne zainteresowania królowej Elżbiety II. 07.07.2010. Polish Community Online. (http://londynek.net/newslajt/Techniczne+zainteresowania+krolowej+Elzbiety+II+ wiadomosci,/newslajt/article?jdnews_id=403, dostęp 19.10.2012).

The Queens Early Life. The British Monarchy. (http://www.royal.gov.uk/HMTheQueen/ Earlylife/Earlylife.aspx, dostęp 20.10. 2012).

U.S. - U.K. RELATIONS. London.UK. (http://london.usembassy.gov/gb.html, dostęp 16.10.2012).

Wpadka Obamy na bankiecie u Królowej. 25.05.2011. UK Polish Community Online. (http://londynek.net/newslajt/Wpadka+Obamy+na+bankiecie+u+Krolowej+wiadomos ci,/newslajt/article?jdnews_id=3004, dostęp: 19.10.2012).

\section{Different Faces of Elizabeth II - What is the Queen Really Like?}

\section{Summary}

Queen Elizabeth II is usually perceived as a reserved monarch. There are just few people who know her other face - that of a mother, wife, and devoted grandmother. This article aims to show these different faces of the British Queen in relation to the different kinds of people such as her family, subjects and also politicians - both British and from the Commonwealth, or Great Britain's closest allies. In addition, this article describes Queen Elizabeth's private life. It shows that in private she is an ordinary woman who has the same needs as millions of other people. Our article also emphasizes the role that the monarch has in her country according to the well-known principle that Queen reigns, but does not rule. 